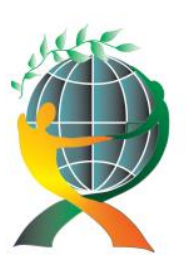

\author{
(online) = ISSN $2285-3642$ \\ ISSN-L = $2285-3642$ \\ Journal of Economic Development, Environment and People \\ Volume 10, Issue 3, 2021
}

URL: http://jedep.spiruharet.ro

e-mail: office jedep@spiruharet.ro

\title{
Plantain Theory and the Attainment of SDGs 2030 by African States: An Exposition
}

\author{
Etim O. Frank ${ }^{10}$, Wilfred I Ukpere ${ }^{2}$ \\ ${ }^{1}$ Department of Political Science and Administration \\ University of Uyo, Akwa Ibom State, Nigeria \\ ${ }^{2}$ Department of Industrial Psychology and People Management, School of Management, \\ College of Business \& Economics, University of Johannesburg, South Africa
}

\begin{abstract}
Agenda 2030 is the Sustainable Development Goals with 17 indicators. Like its predecessors, Millennium Development Goals (MDGs), with only eight goals yet African states could not achieve half of the eight goals then and may not get close to a quarter of the SDGs because of the pathologies of development which are legendary in Africa. This study evaluated the feasibility of using the Plantain tree crop, in which many African countries have global comparative advantage as a means to attaining seven or 41.17 per cent of the 17 goals, against one-sizefit-all approach often applied to such development agenda. The method of study was descriptive which through its procedure revealed, that these countries were not putting this crop and its properties to optimum usage. This approach was complemented by observations and triangulation by library researches on the various usages of plantain tree. The technique included informal interviews of traditional medicine practitioners on the ailments cured through the use of plantain properties. The tactic of the study further revealed that the life-span of plantain is about 20 years, hence it can feed the present and future generation, it withstands every climatic condition, and the fruit could be eaten ripe, unripe, as chips, as plantain flour and paste use in pharmaceutical industries for drugs making. Every part of the plantain tree is use by alternative medicine practitioners. It resolved that the countries that have global comparative advantage with plantain, could harness all the economic and medicinal advantages to achieve the SDGs by 2030 without borrowing in the face of heavy indebtedness. Political will and leadership as well as investments are some of the requirements needed to achieve the goals proposed herein, which affirms the efficacy of Plantain theory as a mechanism towards achieving some percentages of the SDGs by some African States.
\end{abstract}

Keyword: Civil society, Development Global system, Plantain theory, Sustainable Jel Classification: $A 13 ; A 19$

How to cite: Frank, E., \& Ukpere, W. (2021). Plantain Theory and the Attainment of SDGs 2030 by African States: An Exposition. Journal of Economic Development, Environment and People, 10(3), 99111. doi: http://dx.doi.org/10.26458/iedep.v10i3.701

\footnotetext{
+ Corresponding author. Tel.: + (234-9065961735); E-mail address wajorde@gmail.com
} 


\section{Introduction}

The third world states particularly the African members of this group are endowed with enormous resources, some of which have not been discovered, yet they remain very poor nations. The poverty of African states is indeed a paradox because the various resources required to generate development are often within but for the pathologies of development in Africa. It was this persistent incapacity of the continent and its poverty as well as that of other members of the infamous club of the poor nations that caused the world community to initiate the erstwhile Millennium Development Goals (MDGs) in the year 2000, consisting of only eight (8) global development goals, with 2015 dateline for the achievement of certain level of socio-economic development for the continent and other third world states. The pathologies of lack of leadership, fragmented economies and technical backwardness made it impossible to make progress on the MDGs platform.

One of the efforts pursuant to these goals by the G8 or the eight advanced economies of Europe was the promise to channel fiscal resources through the African Development Bank (AFDB), the International Monetary Fund (IMF) and the World Bank. This was the first global mistake made pursuant to the realization of the defunct MDGs, where one-size-fit-all solution was designed to assist Africa and other $3^{\text {rd }}$ world countries to achieve these goals. The total amount committed was not made known but at the close of 2015, almost none of these states made any significant progress in the realization of any the goals. The indignity of multi-dimensional poverty continues in these states unabated with dire consequences.

The SDGs was made to replace the woefully failed MDGs packaged from variables drawn from:(i) the 1972 Stockholm, Sweden conference on Human Environment (ii) the 1983, UN World Commission on Environment and Development, under the chairmanship of the Norwegian Prime Minister Gro Harlem Brundtland, which submitted its final report tagged, 'Our Common Future', (iii) the United Nations Conference on the Environment and Development-the Earth Summit held in Rio de Janeiro in 1992, where the imperative of inventing specific universal environmental, political, and economic values were planned, (iv) COP21 Paris conference, (v) Sendai Framework for Disaster Risk Reduction-Japan 2015. The syntheses of all these defined 'Sustainable Development' which amounts to 'meeting the needs of the present generation without compromising the ability of future generations to meet their own needs (Brundtland commission,1987).

By resolution 70/1, the United Nations General Assembly (UNGA) set the 2030 agenda, which were adopted on 25 September 2015 by 193 countries titled 'Transforming Our World: the 2030 Agenda for Sustainable Development' with 17 goals and their indicators. These goals intend amongst others to: end poverty in all its forms everywhere; end hunger through food security and improve nutrition to ensure healthy living; ensure inclusive and equitable quality of education; achieve gender equality and empower all women, including girls; ensure sustainable management of water; ensure access to affordable energy, inclusive and sustainable economic growth, build resilient infrastructure and industrialization, and reduce inequality within and among countries. The others include to: make human settlements inclusive, safe, resilient and sustainable; attain sustainable consumption and production, combat climate change, conserve use of the oceans, seas and marine resources; protect the ecosystem; attain peaceful and inclusive society and strengthen the mechanisms of implementation(en.m.wikipedia.org 30/09/19). These elaborate goals seem to pose greater challenge to African state based on Albert Hirschman's (1995) 'failure-prone policy process' wherein according 


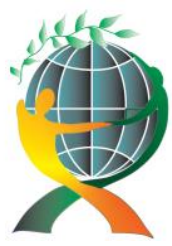

\author{
(online) = ISSN $2285-3642$ \\ ISSN-L = $2285-3642$ \\ Journal of Economic Development, Environment and People \\ Volume 10, Issue 3, 2021 \\ URL: http://jedep.spiruharet.ro \\ e-mail: office jedep@spiruharet.ro
}

to him, developing countries hardly have governments with appropriate policy making apparatus to adequately produce a comprehensive programme. This obvious inadequacy seems to have been addressed by the introduction of policy solutions from 'elsewhere' usually from advanced developed economies, which are hardly suitable for resolving poor nations' domestic challenges. Considering the status quo, how could anyone reasonably expect poor nations, particularly in Africa to meet the SDGs? This is one of the major concern and focus of this study.

\title{
2. The aim of the study
}

2.1. The scope of this study covered the African states of Cameroon, Ghana, Nigeria Cote D'Ivoire and DR Congo who are among the world leading producers of Plantain 'musa-paradisica'. According to the World Bank, Cameroon external debt profile in 2021 is $\$ 30.66240$ billion, Ghana had $\$ 26,953,310,258$ as at 2019 while Nigeria $\$ 84.57$ billion. Cote d' Ivoire has $\$ 29.85$ billion and DR Congo $\$ 13.70$ as at 2009 , which came down to $\$ 7.35$ billion by 2010 . The current debt status by 2021 is still low though not available at moment. Though the least indebted country in Africa has significant financial needs. The debt sustainability analyses for these countries are not encouraging, hence ingenious ways should be initiated for debt reduction, particularly where there are avoidable increases.

\subsection{The objectives of the study}

(i)The main interest of this study was to canvass for the application of the 'Plantain Theory' (Plantain crop- 'musa paradisica') by some of the third world states, to meet about seven (7) of the SDGs, because these countries have global comparative advantage of this food crop over other nations.

The specific goals included: (i) to espouse the health sustainability capacity of the 'plantain crop' (musa paradisica). Put differently, the medicinal properties inherent in all the parts of 'plantain crop' besides its edible and food property could help to achieve the nutritional and economic components of the SDGs.

(ii) To explain the industrial capacity of Plantain tree ranging from food to pharmaceutical usages

(iii) To state that out of the seventeen (17) Sustainable Development Goals, Plantain cultivation and processing could meet goals $1,2,3,5,8,9$ and 12, which is seven (7) out of the seventeen goals. Quantitatively, plantain has the capacity of meeting 41.17 per cent of the Sustainable Development Goals in the countries where they are cultivated and processed.

The Imperative of this study rest on the fact that if only one tree crop, namely Plantain tree (musa paradisica), in which some countries are world producers could be utilized in the attainment of seven (7) or 41.17 per cent of the SDGs, a trend would have been established on how to meet the remaining 58.83 per cent in the third world countries through Self-Reliant approach. 
Another implication of this study is the emphasis not to rely on one- universal- approach towards resolving global problems such as SDGs without taking into consideration of local peculiarities on how to use available resources more effectively. The countries should learn how to look inward to find what endowment they possess and use such to meet their developmental needs toward attaining the SDGs. The indirect benefits of such approach to the concerned countries and communities could be huge. Where the study becomes adaptable, the same process could be applied by states with comparative advantage in any natural endowment or agricultural production, pursuant to the achievement of the SDGs. In order to place this study in context, a literature review was conducted to establish the gaps that existed in order to fill them in the current study as presented below.

\section{Literature Review}

Since the launch of Agenda 2030, otherwise known as the SDGs, there have been considerable bodies of literature on the means to its attainment. They included Kapor and Begashaw (2018)pilot study on how to achieve the SDGs, titled: 'Transformation is Feasible,' where they out rightly averred that if the global states pursue SDGs as they did with the MDGs, the goals attainment would remain an illusion even by the year 2050. Consequently, they proposed a change in the policy tool kit for the SDGs. In their experiences, the pursuit of a piecemeal approach generates trade-offs and conflict among the goals. They recommended an integrated Global System model that would connect the goals as an optimal approach. They termed the identified pathway as 'transformational approach' requiring policy and behavioral changes. This may not work within the African states in line with Albert Hirschman's postulation. Gunnar Myrdal's 'Soft-State' thesis is yet another challenge for African states, who belong to the categories of state characterized by acute social indiscipline such as corruption, arbitrary enforcement of the law, lax or non-existent enforcement of the law and the abuse of power.

The SDG-F Approach (n.d.) was yet another pilot study that was focused on three (3) thematic areas of the Agenda, namely inclusive economic growth; food security and nutrition, water and sanitation. It entails the use of traditional and non-traditional actors pursuant to these goals. It was directed towards achieving a synergy between National Government, Civil Society Organizations, business and academia in 21 countries in Africa, Latin America, Asia and the Arab States.

This approach sought to obtain up to 55 percent of the fund required to attain the SDG goals in these countries. However, the question is, when was the cost for the SDGs established and why do they not reflect as budgetary items in the budget of most of these countries? For instance, in the case Nigeria, where we are conversant with the yearly budgets, there is no item on the line relating to SDGs. More ridiculous is the desire to source these funds from outside the government. Hence, we posit that this may be an impossible task especially in Nigeria, where the private sector would not get involved in any venture without a reasonable payback. It was this type of approach that resulted in the failure of the MDGs.

The relevance of this literature to the current study is the inclusiveness of both orthodox and nonorthodox actors towards achieving the SDGs. Therefore, it reinforces the position of this study, where unorthodox approach has been included towards achieving the SDGs. Hence, it supports the adoption of the plantain and alternative medical practices in these countries. In other words, the position of this study supports the use of plantain to create wealth, nutrition, address poverty as well as use its various components as contents of alternative medicine for health related issues.

SDG-academy (2018) an initiative of SD solutions Network, outlined seven (7) modules to teach the world communities how to achieve the goals specified in the Agenda 2030 document. An interesting 


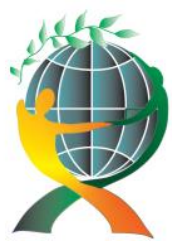

\author{
(online) = ISSN $2285-3642$ \\ ISSN-L = $2285-3642$ \\ Journal of Economic Development, Environment and People \\ Volume 10, Issue 3, 2021 \\ URL: http://jedep.spiruharet.ro \\ e-mail: office jedep@spiruharet.ro
}

and relevant input was made in module 4, which dealt with financing SDGs. It averred that there should be a 'Need Assessment' of each state in order to ascertain the requirements and inputs needed from all stakeholders to meet the SDGs. This proposition provided the space for a study of this nature, which proposed the use of plantain crop that these countries have comparative advantages on as well as use its components as inputs for alternative medicine.

Frank (2016) examined the impediments to the actualization of the MDGs, and averred that the same obstructions would confront the realization of the SDGs. These variables include the nature of the public policy, which has been considered grossly ineffective. This is because after every budget circle, there is often no value-added to the wellbeing of Nigerians because the productive forces are not being developed. The other variable is that the third world and specifically African economies is donor driven. The donors would always determine which sector to invest their donations. This is often not in the social sector where the SDGs belong. Mismanagement of domestic economies, trampling on people's right, debt burden (for instance, out of Nigeria's 2020 budget, about 10.3 trillion was borrowed with 2.5 trillion for foreign debt servicing. In other words, almost a quarter of the budget would go for servicing debt) and apparent lack of leadership and good governance are likely to come on the way SDGs realization as they did to MDGs.

The reviews indicate that none of the literatures advocated for each country to use what it has comparative advantage on in a global scale to meet some of the SDGs. The holistic approach canvassed by other studies could remain elusive owing to differential 'need assessment'. Consequently, this study approached the attainment of the SDGs through the utilization of Plantain crop, which ten (10) of the countries in the study are global producers. Accelerated production of plantain would meet seven (7) or 41.17 per cent of the goals. This is the main proposition of this study.

\title{
4. Propositions of the study
}

In this study we made the ensuing propositions (i) when more than half of the populations are encourage to take up the farming of Plantain in these countries with global comparative advantage, then the states are set to meet 41.17 per cent of the SDGs. By 2019 estimate Cameroon has 25.88 million people, Ghana 44.27 million, Nigeria 201 million, Cote D' Ivoire 25.72 million and DR Congo 86.79 million people. The outputs from half of these populations in each country would amount to meeting domestic needs as well as supplying the global market. (ii) Where these countries leadership embark on Self-Reliant pattern of development using plantain cultivation and processing as a stepping stone, they could then be on the path towards meeting SDGs within the target date. (iii) In order for Self-Reliant development to be meaningful, the 'State-led' development approach should be the platform. (iv) It is anticipated that the entire gamut of the value-chain in plantain cultivation consisting of large hectare cultivation, pest-control harvesting storage, processing into various flour and paste for pharmaceutical industries, market development and exporting according to the standard 
requirements of various markets would be painstakingly done. These propositions have been made based on the fact that post-harvest decay of the products remains a major challenge but could be surmounted with credible leadership and political will on the Self-Reliant' track.

\subsection{The Problem}

The final report of the MDGs at the close of its lifespan was dismal particularly for African countries known for poor political and corporate governance. The commencement of SDGs should not hold greater hope for these set of countries owing to the variables, which impeded the success of the MDGs, such as cultural values, inadequate public policy articulation, dependent economy, domestic mismanagement of the economies, trampling on the citizen's rights, debt burden, absence of political will and leadership to redistribute wealth to all social classes, and xenophobic attacks, are very much endemic amongst Africa states.

The fear is appropriately situated because the unfulfilled goals of the defunct MDGs were extended into the SDGs, while the impeding variables remained constant in these states. The main argument is that the cultivation of Plantain tree crop -'musa paradisica' could be utilize to achieve the following goals: \#1-End poverty in all its forms everywhere in these African states, \#2-End hunger, achieve food security and improved nutrition, as well as promote sustainable agriculture, \#3-Ensure healthy living and promote wellbeing for all ages, \#5-Achieve gender equality and the empowerment of women and girls, \#8-Promote inclusive and sustainable economic growth, full and productive employment and decent work, \#9-Build resilient infrastructure, promote inclusive and sustainable industrialization and foster innovation, \#10-Reduce inequality within and among countries, and \#12-Ensure sustainable consumption and production patterns. Given the feasibility of the Plantain crops to be able to achieve 41.17 per cent of the SDGs, some of the African states would be left with the challenges of 58.83 per cent. The crux of the matter then is on the procedure. This is what the study addressed in subsequent sections and analyses.

It is important to contextualize these eight goals in order to situate them in the proper area of human development. A critical examination of the eight goals would reveal that it stressed food security and the processes of obtaining it on a regular basis for peoples' healthy living. Healthy living of course, would boost the capacity to produce adequate food as the needs arises. Healthy life is connected thereto and entails possessing the purchasing power parity to acquire the necessary food component when needed. Poverty does not discriminate on gender basis, therefore any 'Pareto optimality' generated through the Plantain theory should be inclusive. Inclusive growth and improvement should include all social aggregate in the country. It is only when this is done that the development attained by the state could be regarded as sustainable otherwise the excluded social class may disturb the contented group.

It is precisely because the Plantain crop is resilient to withstand all adverse weather condition that it has been chosen as the main theoretical framework. The Plantain trees remain alive and productive for a minimum of twenty years producing and feeding the present and future generations. It is indeed truism that a sustained cultivation of Plantain, organized marketing and the income generated thereof would not only upset inequality in these states but could turn Small-Scale-Enterprises (SMEs) into a business-chain, comprising the supply of plantain seedlings, cultivation inputs, plantain flour making, packaging firms with employment generated at each level of conversion processes. This is where the indirect beneficiaries would emerge from, which ultimately leads to the attainment of sustainable development goals. 


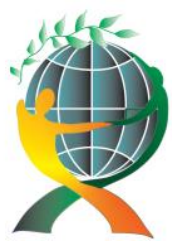

\author{
(online) = ISSN $2285-3642$ \\ ISSN-L = $2285-3642$ \\ Journal of Economic Development, Environment and People \\ Volume 10, Issue 3, 2021 \\ URL: http://jedep.spiruharet.ro \\ e-mail: office jedep@spiruharet.ro
}

\title{
4.2. Methodology of Study
}

The study design was descriptive because it was aimed at accurately and systematically describing the phenomenon under study. It was concern with identifying what the situation currently was about the subject matter. The main thrust of this design was the gathering of data that describe events, which took place independent of the researcher. We utilized descriptive adjective to organize the data in a qualitative format.

Basically it was meant to find out 'what are' the options of some African countries using the plantain crop, which they have comparative advantage on to attain certain goals of the sustainable development agendas. The Procedure included observations, interviews and drawing extensively from secondary sources, whereby the agricultural endowments of these states were studied. It revealed that Cameroon, Ghana, Uganda, Nigeria, Cote d'Ivoire and DR Congo are world producers of Plantain. At the same time, these countries belong to the group of world poorest states. In Global Poverty Index, (GPI), Cameroon the world leading producer of Plantain with annual turnover of 4.31 million tones is \#39 in the Global Poverty Index, Ghana with 3.95 million metric tons is \#50 (GPI), Uganda 3.71 is \#19, Nigeria, 3.09 is \#57, Cote d'Ivoire, 1.59 is \#45, and DR Congo, 1.11 is \#3 (World Atlas, 2018).

These secondary data were deployed in the analysis because a lot had been done on the subject matter of SDGs and how to achieve its objectives. Hence, the abundance of data made the utilization of primary data unnecessary. These were however triangulation of data from various sources to enhance the quality of the study.

The countries in this study are mainly those that could not get close to half the mark on the MDGs scale at the end of 2015 and are not likely to do better on the SDGs continuum with the kind of socioeconomic intervention canvassed herein. Consequent upon the above, this study set out to explore the option of using Plantain (musa paradisiac), which they have comparative advantage on over other countries at a global level, as a mechanism for achieving seven (7) out of the seventeen (17) Sustainable Development Goals. The study affirmed that it is plausible to meet seven of these goals through proper management of plantain production in the aforementioned African countries. It is a situation of using what you have in abundance to achieve some percentage of what you want (SelfReliance), without borrowing from donors, thereby avoiding being submerged in debt crises.

If these countries have the above stated Global Poverty Indices, what guarantee is there that they would be able to realize the seven (7) Sustainable Development goals? That forms the substance of the research question.

\subsection{Procedure of the Method}

The procedure of the application of the method included an in-depth understanding of the life-cycle of the food crop 'plantain-musa-pradisica'. This revealed that (i) plantain tree, has a minimum life span 
of about twenty years (ii) each tree plantain brings forth several other suckers, (iii) plantain paste is a major raw material for the pharmaceutical industries (iv) plantain could be eaten unripe, ripe or made into chips. (v) That its cultivation, marketing and processing generate great wealth to the cultivators (vi) The dried leaves of plantain when burnt into ashes produces and mix with water and sifted produce potash. (vii) Plantain forms a greater source of medicament for practitioners of alternative medicine in countries where there are concurrent use of herbal and orthodox medicines. (viii) Traditional healers use plantain tree as a major source of medication. This source was complemented with the views of traditional healers interviewed.

\subsection{Framework of Analysis: Self-Reliance}

Self-Reliance was adopted as the appropriate theoretical foundation for this study. It was enunciated by Ralph Waldo Emerson in 1841 in his seminal essay 'Self-Reliance' (1803-1882). The aspects of the phenomenon which this study found relevant to his study rests on the following provisions (i) it is thinking independently away from the customary mindset of $3^{\text {rd }}$ world leaders that without 'foreign aid', there can be no development taking place in the $3^{\text {rd }}$ world states. This perspective forbade a state leadership from imitating what others do. (ii) Secondly, it proposed standing out and using the resources available in abundance in a nation (in this case, Plantain). What one has comparative advantage over others should be deployed to the benefit of the citizens in a value added fashion. (iii) The theoretical foundation thus emphasizes the need to bravely strive towards one's own goal without fear, and adopts 'cause and effect' purposeful action to achieve the targeted goals.

The implication of this framework to this study are many, some of which are; (a) depending on others for development strides as most $3^{\text {rd }}$ world leaders do, means that there would be a time when the support would not be available any longer. It is therefore imperative to commence the processes of 'Self-Reliance' as a categorical imperative. Applying this theoretical framework imply that the $3^{\text {rd }}$ world leaders can solve problems and take decisions on their own. (b) Plantain fruit grow all year round with the peak of fruiting in August-December, hence, whatever industrial inputs that require plantain-cannot be in short supply all year round. Production would continue steadily as well as consistent income flow. (c) Nutritional and industrial usages as it is low in fat and a remedy for high blood pressure, good for diabetic patients, a source of vitamins and minerals and rich in protein. The industrial uses include bread and biscuits making flour, etc. It also serves as raw material for food beverages (baby foods, adult powdered food), pharmaceuticals uses as drug-vector (ripe plantain paste as drugs vector for babies and unripe for adult drugs).

Igwe (2005 p.396-7) referred to the concept as a 'policy favoring the optimal utilization of domestic potentials before recourse to outside assistance. 'Self-Reliance' is simply saying that there is a lot that the people can do for themselves and that they need to tap into such resources and potential before lining up to beg for foreign Aids or loans. It is perceived as a legitimate, natural and worthy doctrine that expressed the determined vows that the newly independent states are indeed free.

It favors the mobilization of the people for Africa's own industrial revolution and an unfettered Marshal Plan. The challenge of the practice of Self-Reliance in the $3^{\text {rd }}$ world states is the lack of political will, corrupt and inept leaders who enriched themselves while inflicting criminal acts on the people, many domestic crises gulped the resources, which ought to have been devoted to development. The borrowing binge converted Self-Reliance into external reliance and debt trap. 


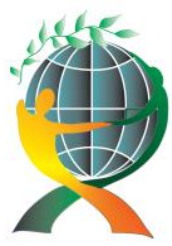

\author{
(online) = ISSN $2285-3642$ \\ ISSN-L = $2285-3642$ \\ Journal of Economic Development, Environment and People \\ Volume 10, Issue 3, 2021 \\ URL: http://jedep.spiruharet.ro \\ e-mail: office jedep@spiruharet.ro
}

It is instructive to note that both sources of the phenomenon of 'Self-Reliance' theory, espouses the following facts: it required State leadership, economic diplomacy to prepare the market, and political will to embark on this policy initiative.

\title{
4.3 Assumptions of the principles
}

i) In the countries where plantain is the mainstay of the economies, more than halve the population should be involve in the cultivation.

ii)That there would be extensive 'value-chains' in the production of plantain ranging from land preparation, pest control, cultivation, harvesting and storage, processing or value-addition and market development. There should be industrial investments to process the harvests.

iii) That the state through the farmers' cooperative would obtain specifications such as 'EEC Regulation 2092/91' which specified the standard that must be reached in the plantain processing to be allowed into the European Union countries -'market development'.

iv) Another supposition of this theory is that, the resources that would be earned thereof would lessen 'bi and multi-lateral loans' and strengthen the pursuit of the SDGs. It is instructive to note that these countries are already heavily indebted ones.

\section{Findings and Discussion}

i) Food-the application of the method of this study, revealed that Cameroon $(4.31, \# 39)$, Ghana (3.95, \#50), Uganda (3.71, \#19), Nigeria (3.09, \#57), Cote d'Ivoire (1.59, \#45), DR Congo (1.11, \#3). The above countries with million tons of Plantain production capacity as indicated in the first figures in parenthesis and their poverty index number as indicated in the second figure in the parenthesis would achieve SD Goals (\#1\& 2) when use as food (ripe and unripe), processed into plantain chips and flour. ii) Drug- These countries would ensure healthy living and promote wellbeing for all at all ages (SDGs \#3) in their domain through the use of plantain as not only food but as drug and Alternative medicine. The green leaves of the plant are medicinal for the treatment of diabetes mellitus (DM) a metabolic disorder in which there are high blood sugar levels over a prolong period, cause by the inability of the metabolic process to break glucose, otherwise known as blood sugar) when boiled and sift and taken twice daily for about 21 days. It reduces the intensity of the disease and gradually causes it to vanish. It is instructive to state that pregnant women should abstain from this medication as it stimulates the uterus, thus, capable of triggering miscarriage or loss of pregnancy (Owobio, 2020).

iii) Traditional Medicine Properties 
a) The whitish substance that comes out when plantain leaf stem is cut -is an effective remedy for the treatment of fresh wounds. It forms clots and stops the flow of blood almost immediately. This could be collected in a bottle and stored below room temperature and utilized as required.

b) The Plantain Sap, which is obtained when the trunk of 'musa paradisiac' is cut into pieces, pounded with mortar and the juice squeezed out. A bottle of the herbal juice or sap obtained when mixed with half bottle of honey, provide Plantain Herbal solution, which is a curative for the following diseases: nervousness, epilepsy, dysentery, wound in the stomach wall and skin infections, the roots is a portent poison. Roasted plantain on the other hand serves many uses in men's oligospermia.

c) It is instructive to note that gender equality could be attained through plantain cultivation because in Africa and specifically in countries within the scope of this study, women are mostly farmers. Incomes from plantain cultivation would enable them to stand at par with their male counterparts. Based on that other stereotypical 'cultural misgiven' are eliminated. Sustainable economic growth (goal 8) would be achieved when a state develops simultaneously the other sectors of the economy that will be complemented by the Plantain crop input. Goal (9) which relate to the building of resilient infrastructure could be achieved through processing plants for the extraction of Psyllium (food thickner). That is derive from plantain the primary property in the manufacture of laxative drugs. The Plantain starch/paste is a major agent in Pharmaceutical industries for the production of drugs for various ailments (Otongebung, 2020).

\subsection{Critical reflections}

In fact, the Russian Ministry of Health came to the realization that juice from crushed plantain leaves cure several stomach related ailments, and hence incorporated it into its health system program. The German Commission on Herbal and Alternative Medical practices list plantain as a safe and effective herb for anti-bacterial treatment. The Italian Herbal Commission confirmed it uses as a potent input in its alternative medicine practices. The Chinese on the other hand, recognized plantain as a major input in the treatment of male-impotency.

When the advantages derived by many developed nations from Plantain are taken into consideration by the five (5) African countries in this study, they could become capable of meeting seven (7) goals out of the seventeen (17) SDGs, which were the focus of this study.

It is herein stated that the environment would not be adversely affected due to the cultivation of plantain and the introduction of technology to extract the juice from plantain stems, leaves and roots for medicinal purposes in these states. It would be an added advantage to the countries in this study to adopt technology in extracting the medical properties of plantain as well as while using it as food in various forms.

\subsection{Envisaged Challenges}

The fundamental challenges envisaged in the pursuit of Self-Reliance development through the novel application of Plantain theory to sustainable development was captured by Albert Hirschman (1995) when he posited that developing countries hardly possess governments with the policy-making apparatus, adequate to the task of producing a comprehensive program. This inadequacy is met by the introduction of policy solutions from 'elsewhere' usually from advanced economies, which are hardly suitable for local problems. This often undermines the capacity of local intellectual resources, deepens the underdevelopment of local intellectual resources towards addressing local problems. 


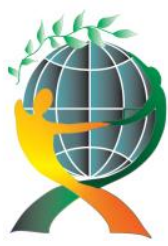

\author{
(online) = ISSN $2285-3642$ \\ ISSN-L = $2285-3642$ \\ Journal of Economic Development, Environment and People \\ Volume 10, Issue 3, 2021 \\ URL: http://jedep.spiruharet.ro \\ e-mail: office jedep@spiruharet.ro
}

Another critical challenge is what Gunnar Myrdal (1968) termed 'soft states'. States in this category suffer from acute social indiscipline such as corruption, arbitrary enforcement of the law, lax or nonexistent enforcement of the law and abuse of power. In addition, there have been few checks on unrestrained and abused of power by dominant executives and their representatives.

The other challenge envisaged is the absence of political will to embark on 'Self Reliance' development, since most $3^{\text {rd }}$ world leaders are subservient to Western powers' control. The other challenges include obtaining the appropriate size of land for the cultivation, pest control to enable the plantain seedlings grow into maturity, understanding the requirements of the international markets that would be entered and bringing the quality of plantain products to the standard level in order to access the markets, such as the 'EEC 2002/91, USA 'Prosper Africa and African Growth and Opportunity Act (AGOA)', which are guidelines for Africa to access American markets with their products. These countries are known to have infrastructural deficit, therefore storage facilities to store the store processed or harvested product might constitute a major challenge. These challenges are surmountable with purposeful leadership.

\title{
5.4 Validation of the study submission
}

It is pertinent to restate that the objectives of the study have been realized while the propositions are feasible given that Russia, Germany and France have all adopted the healing potentials of the different components of the plantain crop into their healthcare system. Jethro Kloss (1990) in the work 'Back to Eden' has illustrated the efficacy of the study submission, while Werner, Carol and Maxwell in 'Where There Is No Doctor' has also affirmed the feasibility of the submissions of this study.

\section{Conclusion}

The sustainable development circle of man, environment and technology could be achieved when the Plantain is used as discussed in this study. Given the data presented and analyses made, we herein conclude that, the usual one-size-fit-all solution for resolving global problem, is no longer relevant where SDGs and the plantain crop is in abundance. The countries have different 'need requirements; hence one should use whatever it has comparative advantage on as a platform of 'Self-Reliance' to pursue the SDGs, as demonstrated in this study.

The present study has shown how Plantain crop could be use both as food, article for trade and medicine to meet seven (7) out of the seventeen (17) SDGs. We have illustrated the processes through which plantain tree crop could be utilized in the economy to end poverty and hunger, as well as improve the nutritional and healthy living of the people. The wealth generated from its cultivation and management, could change gender imbalance because in many of these countries the bulk of the cultivators are women and this pushes the frontiers for inclusive economic growth. 
The linkages of wealth from plantain-tree-crop require industries for the processing of plantain into flour, chips, and paste for pharmaceuticals as well alkaline water obtained from burning dried cover of plantain fruit. The building of these plantain related infrastructure would enrich the cultivators and reduce inequality of income as well as ensue sustainable consumption. The success of these countries through 'Self-Reliance' approach could be duplicated by all other countries that intend to use resources, which they have advantage on over others. In a nutshell, 'Self-Reliant' approach through the application of the plantain theory could accelerate the attainment of the SDGs by 2030 in the aforementioned African states.

\section{References}

[1] Amaya, N. (2018) 'The World Leading Plantain Producers. World Atlas, May 28, 2018 worldatlas.com/articles/the world leading plantain producers' html. Accessed 27/09/19

[2] Atlas \& Boots 2018-Ranking of Poorest countries in the world, USA: World Atlas

[3] Emerson, R. W. (1841). Self-Reliance. Boston, Massachusetts. Project Gutenberg. November, 2019 www.gutenberg.org/ebooks/1643

[4] Frank, E. O. (2015) Plantain Theory of Sustainable Development -Infinity Journal of Sustainable Development Studies, Vol.8(2) pp 294-316 China

[5] Frank, E. O. (2016) Actualization of the MDGs in Africa by 2015; A Study of Impediments -Uyo Journal of Sustainable Development vol. 1(1) Jan-June p176-189

[6] Fundukian, L. J. (2001) Gale Encyclopedia of Alternative Medicine. Cengage

[7] Hirschman, A. O. (1995). A Propensity for Self Subversion. Cambridge: Harvard University Press

[8] Igwe, O. (2005). Politics and Globe Dictionary, New Edition Aba: Eagle Publishers

[9] Kapor, S. and Begashaw, B. (2018). Transforming is Feasible- A Report to the club of Rome, for its 50 years' anniversary 17 October 2018. Stockholm Resilience Centre Report, Oct. 2018.

[10] Kloss, J.(1999). Back to Eden-classic guide to Herbal Medicine natural foods and Home remedies since 1939. Twin Lakes USA: Lotus Press

[11] Longe, J. L. (2001) Gale Encyclopedia of Alternative Medicine Gale, Cengage Vol.2 2014

[12] Myrdal, G. (1968) Asian Drama: An Inquiry into the Poverty of Nations. USA: Pantheon Publishers.

[13] Nicholas C. (1990) Complete Herbal \& English Physician IL. Meyer brooks

[14] Otongebung, I. (2020). Interview conducted with a Native Doctor on the use of Plantain properties as curative medicine-October 10, at his home-Udung Uko-Oron Local Government Area-Akwa Ibom State-Nigeria.

[15] Owobio, P. (2020) Interview conducted with Traditional Healer with 30 years' experience-in Oron LGA-Akwa Ibom State -November 20 at his residence on the 'use of plantain properties for medication'. 


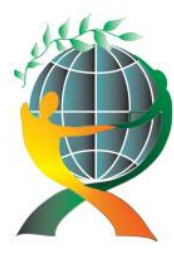

\author{
(online) $=$ ISSN $2285-3642$ \\ ISSN-L = $2285-3642$ \\ Journal of Economic Development, Environment and People \\ Volume 10, Issue 3, 2021 \\ URL: http://jedep.spiruharet.ro \\ e-mail: office jedep@spiruharet.ro
}

[16] Pelletier, K. R. (2002) the Best Alternative Medicine. Part1: Western Herbal Medicine. N:Y Simon \& Schuster

[17] SDG-academy@ UNSDSN.ORG (2018) 475 Riverside Drive Suit 530 NY 10115 USA

[18] SDG-Fund Approach (n.d) Secretariat One United Nations Plaza, DC1-1950 NY 10017

(En.m.wikipedia.org 30/09/19) accessed 2020

[19] Werner, D. Carol, T. Maxwell, J. (1992) Where There Is No Doctor. Hesperian Health Guide

[20] Myrdal, G. (1968) Asian Drama: An Inquiry into the Poverty of Nations. USA: Pantheon Publishers 